KatARZYNA JADACH

ORCID 0000-0002-4875-6558

Uniwersytet im. Adama Mickiewicza

$w$ Poznaniu

\title{
DYREKTOR SZKOŁY W ROLI PRACODAWCY - PRZEGLĄD WYBRANYCH ZAGADNIEŃ FUNKCJONOWANIA SZKOŁY JAKO ZAKŁADU PRACY
}

\begin{abstract}
Jadach Katarzyna, Dyrektor szkoły w roli pracodawcy - przeglad wybranych zagadnien funkcjonowania szkoty jako zakładu pracy [The Headteacher as an Employer - a Review of Selected Issues of the School as a Workplace]. Studia Edukacyjne nr 57, 2020, Poznań 2020, pp. 119-144. Adam Mickiewicz University Press. ISSN 1233-6688. DOI: 10.14746/se.2020.57.9

One of the basic tasks that the provisions of the educational law entrust to the headteacher is to be in an employment relationship with the teachers as employees. This role is determined by the status of the educational institution as a workplace, to which the sources of universally and internally binding labor law apply. They impose a number of obligations on the employer, i.e. the headteacher, which should be interpreted in the light of the unique educational, teaching and tutoring tasks implemented within the units of the education system. Principal autonomy is also influenced by the imperative of implication in the educational reality the clause of the child's good. It is done by application of specific legal provisions, in particular making decisions that create the internal policy of the school staff.
\end{abstract}

Key words: headteacher, workplace, employee relationship, teacher's duties, employee's responsibility

\section{Wstęp}

Szkoła charakteryzowana jest przede wszystkim jako miejsce organizowania procesów dydaktycznych, w którym uczeń staje się odbiorcą określonych podstawami programowymi treści edukacyjnych. W ujęciu tym istota funkcjonowania placówki oświatowej zasadza się w stopniu przyswojenia wymaganych treści, czego formalny wyraz stanowi poziom uzyskanego wykształcenia. Działalność stricte dydaktyczną uzupełniają wysiłki wychowawcze, których ogólny kierunek wyznaczają normy konstytucyjne (Prawo rodziców do wychowania dziecka zgodnie z własnymi przekonaniami za- 
gwarantowane w art. 48 Konstytucji RP) oraz te konstruowane na podstawie regulacji Prawa rodzinnego (przede wszystkim zasada autonomii rodziny, ale również zasada pomocniczości). Podkreślając rodzicielski prymat w wychowaniu dziecka, nakładają one na jednostki organizacyjne systemu oświaty obowiązek wspierania rodziców w pracy na rzecz „rozwoju dziecka ku pełnej dojrzałości w sferze fizycznej, emocjonalnej, intelektualnej, duchowej i społecznej" oraz w kształtowaniu u dziecka postaw prospołecznych (art. 1 ustawy Prawo oświatowe z 14.12.2016 r. ${ }^{1}$, w skrócie PrOświat).

Postrzeganiu szkoły przez pryzmat funkcjonalnej charakterystyki opartej na analizie jej zadań statutowych powinna towarzyszyć refleksja nad tym aspektem jej działalności, jaki determinują przepisy prawa pracy. Szkoła stanowi bowiem dla nauczycieli, wychowawców i innych pracowników pedagogicznych miejsce, w którym w ramach stosunku zatrudnienia świadczą oni usługi edukacyjne $\mathrm{w}$ zamian za wynagrodzenie. $\mathrm{W}$ takim ujęciu placówkę oświatową należy traktować jako zakład pracy, spełniający warunki organizacyjnego wyodrębnienia (posiadanie finansowej samodzielności, organów, pracowników, środków rzeczowych, kierownika reprezentującego zakład na zewnątrz) i zdolny do zatrudniania pracowników². Przywołany kontekst narzuca sposób patrzenia na dyrektora szkoły - jest on nie tylko organizatorem działań dydaktyczno-wychowawczych placówki, pierwszym nauczycielem i wychowawcą, gospodarzem obiektu szkolnego, ale również pracodawcą ${ }^{3}$. Z perspektywy stosunków łączących dyrektora z nauczycielami, rola podmiotu zatrudniającego jest podstawowa; pośrednio jednak sposób, w jaki dyrektor wywiązuje się ze swoich obowiązków jako pracodawca wpływa na jakość relacji z rodzicami, organem nadzoru pedagogicznego, organem prowadzącym, środowiskiem lokalnym, placówkami i instytucjami, z którymi szkoła powinna współpracować.

\section{Dyrektor szkoły jako pracodawca w przepisach prawa oświatowego}

Na funkcjonowanie dyrektora jako pracodawcy zwraca się uwagę w podstawowych aktach prawa oświatowego. W przepisach PrOświat regulujących problematykę kompetencji dyrektora (art. 68 ust. 1), w sferze jego działalności skierowanej "do wewnątrz” (czyli w ramach stosunków wewnątrzzakładowych) - określonej jako kierowanie działalnością szkoły lub placówki - dyrektor realizuje politykę kadrową. Jako kierownik zakładu pracy dla

1 T.j. DzU z 2019 r. poz. 1148 ze zm.

2 Por. uchwała Sądu Najwyższego z 16.11.1977 r., I PZP 47/77, Legalis.

${ }^{3}$ T. Komorowski, J. Pielachowski, Dyrektor szkoty w roli pracodawcy, Poznań 2004, s. 11. 
zatrudnionych nauczycieli i pracowników niebędących nauczycielami dyrektor decyduje w szczególności w sprawach: ich zatrudniania i zwalniania; przyznawania nagród oraz wymierzania kar porządkowych; występowania z wnioskami w sprawach odznaczeń, nagród i innych wyróżnień (art. 68 ust. 5). W sferze działalności skierowanej „na zewnątrz” dyrektor reprezentuje szkołę przed innymi podmiotami, współdziałając z nimi w sposób mniej bądź bardziej sformalizowany (np. poprzez zawieranie umów cywilnoprawnych) w obszarach, w których możliwe jest wypełnianie podstawowych funkcji szkoły. W ustawie z 26.01.1982 r. Karta Nauczyciela ${ }^{4}$ (w skrócie KartaNauczU) podobnie akcentuje się działalność dyrektora, polegającą z jednej strony na kierowaniu placówką i byciu przełożonym służbowym wszystkich pracowników, z drugiej - reprezentowaniu jej na zewnątrz (art. 7 ust. 1). W literaturze przedmiotu słusznie podkreśla się, iż przywołane wyżej określenia: „kierowanie szkołą”, ,"reprezentowanie szkoły na zewnątrz”, czy stanowisko "przełożonego służbowego" są równoznaczne z pojęciem pracodawcy5.

Wchodząc $\mathrm{w}$ rolę pracodawcy, dyrektor przyjmuje na siebie obowiązki wynikające z przepisów prawa pracy, do którego zalicza się ${ }^{6}$ : a) przepisy stanowiące źródło powszechnie obowiązującego prawa Rzeczypospolitej Polskiej (art. 87 Konstytucji), czyli: przepisy zawarte w ustawach (przede wszystkim w Kodeksie pracy, ale również $\mathrm{w}$ innych ustawach określających prawa i obowiązki pracowników i pracodawców) oraz przepisy wykonawcze do tych ustaw zawarte w rozporządzeniach; b) postanowienia zawarte $\mathrm{w}$ aktach niebędących źródłami powszechnie obowiązującego prawa Rzeczypospolitej Polskiej, obowiązujące w określonych gałęziach pracy, zawodach, konkretnych zakładach pracy, czyli: układach zbiorowych pracy, innych porozumieniach zbiorowych, regulaminach i statutach, określających prawa i obowiązki stron stosunku pracy. Podstawowym aktem ustawodawstwa pracy jest Kodeks pracy (w skrócie k.p.), jednak nie określa on w sposób zupełny praw i obowiązków wszystkich grup pracowników. W kwestiach uregulowanych w sposób szczególny, w odrębnych ustawach odnoszących się do wybranych kategorii pracowników stosuje się zamiast kodeksu przepisy tych ustaw (art. 5 k.p.), co jest zgodne $\mathrm{z}$ funkcjonującą w polskim systemie prawa zasadą lex specialis derogat legi generali.

Nauczyciele należą do tej grupy pracowników, których stosunek pracy uregulowany został $\mathrm{w}$ akcie szczególnym, $\mathrm{z}$ uwagi na ich zatrudnienie $\mathrm{w}$ wyspecjalizowanych jednostkach wykonujących zadania szczególne ${ }^{7}$. Jest nim

${ }^{4}$ T.j. DzU z 2019 r. poz. 2215.

5 T. Komorowski, J. Pielachowski, Dyrektor szkoty, s. 10.

${ }^{6}$ Art. 9 ustawy z 26.06.1974 r. Kodeks pracy, t.j. DzU z 2019 r. poz. 1495 ze zm.

7 T. Zieliński, G. Goździewicz, Rozdział I. Przepisy wstępne, [w:] Kodeks pracy. Komentarz, red. L. Florek, Warszawa 2017, s. 71. 
KartaNauczU, której fundamentalne znaczenie w obszarze nauczycielskiej pragmatyki zawodowej podkreślone zostało w art. 6 PrOświat („Prawa i obowiązki nauczycieli przedszkoli, szkół i placówek określa ustawa z dnia 26 stycznia 1982 r. Karta Nauczyciela «...»".), ale również w art. 91c samej KartaNa$\mathrm{uczU}^{8}$. Jej przepisy modyfikują treści klasycznego stosunku pracy, nakładając na dyrektorów szkół dodatkowe obowiązki, ale również wyostrzając kryteria naboru do zawodu nauczyciela oraz poszerzając katalog obowiązków i uprawnień pracowniczych. Prawny kontekst funkcjonowania nauczyciela w szkole przyczynia się do postrzegania tego zawodu w kategoriach formacji zaangażowanej w służbę społeczeństwu, od kondycji której zależy stopień realizacji podstawowych funkcji placówki, czyli dydaktyki, wychowywania i opieki nad dziećmi. Pieczę nad jakością świadczonych usług edukacyjnych przepisy prawa powierzyły dyrektorowi, zaopatrując ten organ w szeroki zakres kompetencji oraz odpowiedzialności. Poniżej zwrócono uwagę na elementy wskazujące na specyficzne uwarunkowania zatrudnienia nauczyciela. Dotyczą one przesłanek nawiązania i rozwiązania stosunku pracy, katalogu obowiązków oraz odpowiedzialności prawnej (pracowniczej i dyscyplinarnej).

\section{Zadania dyrektora \\ w zakresie powstania i ustania stosunku pracy z nauczycielem}

Podstawową instytucją prawa pracy jest stosunek pracy, poprzez nawiązanie którego pracownik zobowiązuje się do wykonywania pracy określonego rodzaju na rzecz pracodawcy i pod jego kierownictwem oraz w miejscu i czasie wyznaczonym przez pracodawcę, a pracodawca - do zatrudniania pracownika za wynagrodzeniem (art. 22 k.p.). W przypadku szkoły w rolę pracodawcy wchodzi dyrektor szkoły, zatrudniający nauczyciela na podstawie umowy o pracę lub mianowania na stanowisku zgodnym z posiadanymi przez nauczyciela kwalifikacjami i stopniem awansu zawodowego (art. 11 KartaNauczU).

\footnotetext{
${ }^{8}$ Przywołana ustawa składa się z 15 rozdziałów, w których regulowane są następujące kwestie: obowiązki nauczycieli; wymagania kwalifikacyjne nauczycieli; awans zawodowy nauczycieli; nawiązanie, zmiana i rozwiązanie stosunku pracy; warunki pracy i wynagrodzenie; nagrody i odznaczenia; uprawnienia socjalne i urlopy; finansowanie dokształcania i doskonalenia zawodowego nauczycieli; ochrona zdrowia; odpowiedzialność dyscyplinarna nauczycieli; uprawnienia emerytalne. Poszczególne zagadnienia z obszaru nauczycielskiej pragmatyki zawodowej stanowią przedmiot szczegółowych analiz w ramach opracowań komentatorskich, np.: A. Barański, M. Szymańska, J. Rozwadowska-Skrzeczyńska, Karta Nauczyciela. Komentarz, Warszawa 2018; D. Dwojewski, P. Kuzior, M. Kowalski, Karta Nauczyciela - komentarz praktyczny. Wiedza i praktyka, Warszawa 2018; K. Lisowski, K. Stradomski, Karta Nauczyciela. Komentarz, Warszawa 2018; A. Piszko, Karta Nauczyciela: komentarz, Warszawa 2017.
} 
Analiza wymagań kwalifikacyjnych osób aplikujących na stanowisko nauczyciela (art. 9 KartaNauczU) wskazuje na wprowadzenie kryteriów rekrutacyjnych związanych z cezusem wykształcenia9 (posiadanie wyższego wykształcenia $\mathrm{z}$ odpowiednim przygotowaniem pedagogicznym), moralną postawą (przestrzeganie podstawowych zasad moralnych) oraz stanem zdrowia (spełnianie warunków zdrowotnych niezbędnych do wykonywania zawo$\mathrm{du}$ ). Kryterium merytorycznego przygotowania istotne jest przede wszystkim z punktu widzenia dydaktycznych aspektów działania szkoły, a gwarancje jego spełniania stanowi dyplom ukończenia stosownych studiów lub studium $^{10}$. Brak tego typu kwalifikacji w zasadzie uniemożliwia zatrudnienie na stanowisku nauczyciela ${ }^{11}$. W przypadku kiedy kandydat legitymuje się ukończeniem studiów o kierunku (specjalności), który nie jest zgodny z nauczanym przedmiotem lub prowadzonymi zajęciami, dyrektor zobligowany jest sprawdzić, czy spełnia on wymóg ukończenia kierunku, którego efekty kształcenia w zakresie wiedzy i umiejętności obejmują treści tego przedmiotu lub zajęć wskazane $\mathrm{w}$ podstawie programowej dla danego przedmiotu na odpowiednim etapie edukacyjnym. W związku z wymogiem dotyczącym stanu zdrowia obowiązkiem dyrektora jest kierowanie zatrudnianych osób na wstępne badania lekarskie, co oznacza, że rozpoznania w zakresie zdolności do pracy z dziećmi dokonuje lekarz medycyny pracy ${ }^{12}$. $Z$ kolei, założenie prezentowania przez nauczyciela moralnej postawy weryfikowane jest poprzez zbieranie informacji dotyczących: korzystania z praw publicznych; wykluczenia toczenia się przeciw kandydatowi postępowania karnego w sprawie o umyślne przestępstwo ścigane z oskarżenia publicznego lub postępowania dyscyplinarnego; wykluczenia skazania prawomocnym wyrokiem za umyślne przestępstwo lub umyślne przestępstwo skarbowe; wykluczenia ukarania karą dyscyplinarną zwolnienia z pracy z zakazem przyjmowania ukaranego do pracy w zawodzie

${ }^{9}$ Problematyka kwalifikacji nauczycieli w sposób szczegółowy uregulowana została w rozporządzeniu Ministra Edukacji Narodowej z 01.08.2017 r. w sprawie szczegółowych kwalifikacji wymaganych od nauczycieli, DzU z 2017 r. poz. 1575.

${ }_{10}$ Zob. m.in. wyrok Naczelnego Sądu Administracyjnego z 27.11.2001 r., II SA 2133/01, Legalis.

${ }_{11}$ A. Barański, M. Szymańska, J. Rozwadowska-Skrzeczyńska, Karta Nauczyciela. Komentarz, s. 93. W wyjątkowych przypadkach istnieje jednak możliwość zatrudnienia kandydata bez merytorycznych kwalifikacji. Pierwsze odstępstwo dotyczy potrzeby wynikającej z organizacji nauczania lub konieczności zastąpienia nieobecnego nauczyciela (art. 10 ust. 9 KartaNauczU). Ponadto, możliwie jest zatrudnienie w szkole do prowadzenia zajęć osób niebędących nauczycielami na zasadach określonych w Kodeksie pracy (art. 15 ust. 2 i 3 PrOświat). O wyjątkowości tych sytuacji świadczy fakt, iż decyzja dyrektora o zatrudnieniu takiej osoby poprzedzona musi być zgodą kuratora oświaty.

${ }_{12}$ Dokonuje się to w trybie i na zasadach określonych w Rozporządzeniu Ministra Zdrowia i Opieki Społecznej z 30.05.1996 r. w sprawie przeprowadzania badań lekarskich pracowników, zakresu profilaktycznej opieki zdrowotnej nad pracownikami oraz orzeczeń lekarskich wydawanych do celów przewidzianych w Kodeksie pracy, DzU z 2016 r. poz. 2067. 
nauczyciela w okresie trzech lat od ukarania albo wydalenia z zawodu nauczyciela. Ustalenie faktu niekaralności oraz figurowania kandydata w Centralnym Rejestrze Orzeczeń Dyscyplinarnych ${ }^{13}$ i Rejestrze Sprawców na Tle Seksualnym ${ }^{14}$ dokonywane jest na podstawie dokumentacji papierowej i elektronicznej udostępnianej $\mathrm{w}$ procesie rekrutowania przez samego zainteresowanego (zaświadczenie z Krajowego Rejestru Karnego) bądź poprzez dostęp pracodawcy do rejestrów zawierających dane osobowe ${ }^{15}$ osób ukaranych przez nauczycielskie komisje dyscyplinarne lub skazanych za przestępstwa seksualne.

Podmiotem odpowiedzialnym za weryfikację ustawowych kryteriów jest zatrudniający nauczyciela dyrektor. Wypełnianie przez niego obowiązku przyjmowania do placówki oświatowej osób kompetentnych i niekaranych stanowi przedmiot kontroli, jaką nad placówką sprawuje organ nadzoru pedagogicznego (art. 55 ust. 1 i 2 PrOświat), w szczególności w obszarze oceniania stanu i warunków działalności dydaktycznej, wychowawczej i opiekuńczej oraz innej działalności statutowej szkoły. Osoby prowadzące czynności kontrolne mogą wydawać dyrektorowi zalecenia wynikające z przeprowadzonych czynności wraz z terminem ich realizacji. Są one wiążące, ale dyrektor uprawniony jest do wnoszenia do nich swoich zastrzeżeń do organu sprawującego nadzór pedagogiczny. Jeśli ten zastrzeżeń nie uwzględni - dyrektor musi zalecenia zrealizować. Jeśli zaistniałe uchybienia dotyczą działania sprzecznego z prawem, organ nadzorujący ma legitymację do wydania dyrektorowi polecenia usunięcia uchybień w wyznaczonym terminie (art. 56 ust. 1 PrOświat). Nieusunięcie tego typu uchybień skutkuje wystąpieniem do organu prowadzącego szkołę z wnioskiem o odwołanie dyrektora z końcem albo w czasie roku szkolnego bez wypowiedzenia. Wniosek złożony w tej sprawie przez organ sprawujący nadzór pedagogiczny jest wiążący dla organu prowadzącego szkołę lub placówkę.

${ }^{13}$ W Centralnym Rejestrze Orzeczeń Dyscyplinarnych na podstawie art. 85 w KartaNauczU gromadzone są dane o osobach prawomocnie ukaranych wydaleniem z zawodu nauczycielskiego lub zwolnionych $\mathrm{z}$ pracy z zakazem zatrudnienia $\mathrm{w}$ zawodzie przez trzy lata. Dyrektor szkoły jest jednym z podmiotów, któremu przysługuje prawo do uzyskania informacji $\mathrm{z}$ rejestru w stosunku do osoby ubiegającej się o zatrudnienie na stanowisku nauczyciela oraz nauczycieli zatrudnionych $\mathrm{w}$ danej szkole.

${ }^{14}$ Zgodnie z art. 21.1 Ustawą z 13.05.2016 r. o przeciwdziałaniu zagrożeniom przestępstwami na tle seksualnym, t.j. DzU z 2018 r. poz. 405 ze zm., w przypadku zatrudniania lub dopuszczania osób do innej działalności związanej z wychowaniem, edukacją, wypoczynkiem, leczeniem małoletnich lub opieką nad nimi (np. wyjazdy na ferie zimowe, agroturystyka, obozy jeździeckie) pracodawca lub inny organizator w zakresie takiej działalności ma obowiązek sprawdzenia, czy dane zatrudnianej lub dopuszczanej osoby są zamieszczone w Rejestrze Sprawców na Tle Seksualnym.

${ }^{15}$ Dbałość o posiadanie przez nauczycieli kwalifikacji moralnych widoczna jest na dalszych etapach ich zatrudnienia, o czym świadczy treść art. 26 ust. 1 KartaNauczU, zawierającego przesłanki wygaśnięcia nauczycielskiego stosunku pracy. 
Sposób rozwiązania przez dyrektora szkoły stosunku pracy z nauczycielem zależny jest od posiadanego przez niego stopnia zawodowego oraz podstawy zatrudnienia. Najdalej idące ograniczenia w zakresie rozwiązania stosunku pracy dotyczą nauczycieli zatrudnionych na podstawie mianowania. Wynika to $\mathrm{z}$ istoty mianowania, stanowiącego akt administracyjny o podwójnym skutku, jakim jest nawiązanie stosunku pracy, a zarazem nadanie osobie mianowanej kompetencji do wykonywania funkcji związanej ze stanowiskiem, na które została mianowana ${ }^{16}$. Praca wykonywana w ramach tego rodzaju stosunku wiąże się z większym podporządkowaniem (dyspozycyjnością) pracownika władzy służbowej, podlegającego równocześnie wzmożonej ochronie prawnej. W przypadku tej kategorii nauczycieli rozwiązanie stosunku pracy jest możliwie wyłącznie $\mathrm{w}$ sytuacjach enumeratywnie wskazanych $\mathrm{w}$ art. 23 ust. 1 KartaNauczU, czyli: na wniosek nauczyciela; w razie czasowej niezdolności nauczyciela do pracy spowodowanej chorobą, jeśli okres tej niezdolności przekracza 182 dni, a jeżeli niezdolność do pracy została spowodowana gruźlicą lub występuje $\mathrm{w}$ trakcie ciąży - $270 \mathrm{dni}$; $\mathrm{w}$ razie orzeczenia przez lekarza przeprowadzającego badanie okresowe lub kontrolne o niezdolności nauczyciela do wykonywania dotychczasowej pracy; w razie uzyskania negatywnej oceny pracy; w razie cofnięcia skierowania do nauczania religii w szkole. Jak wynika z powyższego zestawienia, realne możliwości w obszarze prowadzenia przez dyrektora polityki kadrowej względem nauczycieli związanych z placówką oświatową aktem mianowania wynikają $\mathrm{z}$ jego uprawnień przewidzianych $\mathrm{w}$ procedurze oceniania merytorycznego i sprawowania wewnętrznego nadzoru pedagogicznego. $W$ przypadku nauczycieli zatrudnionych na podstawie umowy o pracę na czas nieokreślony przepisy KartaNauczU przewidują prawo każdej ze stron stosunku pracy do jego wypowiedzenia z końcem roku szkolnego, za trzymiesięcznym wypowiedzeniem (art. 27).

Niezależnie od powyższego $\mathrm{w}$ ustawie (art. 20 ust. 1) wskazano obiektywne przesłanki rozwiązania stosunku pracy nauczyciela zatrudnionego na podstawie mianowania oraz umowy o pracę. Dotyczą one całkowitej likwidacji szkoły albo braku możliwości dalszego zatrudnienia w pełnym wymiarze zajęć podyktowanego: częściową likwidacją szkoły, zmianami organizacyjnymi powodującymi zmniejszenie liczby oddziałów w szkole, zmianami w planie nauczania. Dyrektor jako pracodawca powinien rozważyć obiektywne, rzeczywiste, niedyskryminujące i zrozumiałe kryteria doboru do wypowiedzenia (ewentualnie przenoszenia $\mathrm{w}$ stan nieczynny lub ograniczenia zatrudnienia), takie jak: forma zatrudnienia (mianowanie czy umowa o pracę), staż pracy w szkole, posiadanie uprawnień emerytalnych lub do świadczenia

${ }^{16}$ T. Zieliński, Ł. Pisarczyk, Rozdziat III. Stosunek pracy na podstawie powołania, wyboru, mianowania oraz spótdzielczej umowy o prace, [w:] Kodeks pracy, s. 485. 
kompensacyjnego, fakt odmowy przyjęcia propozycji ograniczenia zatrudnienia. Z punktu widzenia specyfiki pracy nauczycielskiej pierwszorzędne znaczenie może mieć: poziom i zakres kwalifikacji zawodowych, w szczególności w zakresie nauczanego przedmiotu ${ }^{17}$, jakość wykonywanej pracy i jej ocena dokonywana przez przełożonego, rodziców i uczniów ${ }^{18}$, dyscyplina pracy ${ }^{19}$ czy dyspozycyjność pracownika i związane z nią długotrwałe nieobecności w pracy ${ }^{20}$.

Od przypadków wypowiedzenia należy odróżnić wygaśniecie stosunku pracy z mocy prawa. Jest ono niezależne od podstawy nawiązania stosunku pracy, w związku z czym odnosi się zarówno do nauczyciela zatrudnionego na podstawie mianowania, jak i umowy o pracę ${ }^{21}$. Przyczyny wygaśnięcia stosunku pracy nauczyciela są $\mathrm{w}$ sposób wyczerpujący wskazane w przepisach prawa i dotyczą one przede wszystkim sytuacji prawomocnego ukarania karą w postępowaniu dyscyplinarnym lub karnym ${ }^{22}$ (art. 26 KartaNauczU). $\mathrm{Z}$ uwagi na automatyczne ustanie stosunku pracy z dniem wystąpienia jednej ze wskazanych w ustawie przesłanek, rola dyrektora w tego typu okolicznościach sprowadza się wyłącznie do deklaratoryjnego stwierdzenia wygaśnięcia stosunku pracy. Brak decyzyjności dyrektora w ocenie naganności powyższych naruszeń w kontekście okoliczności konkretnej sprawy świadczy o wadze, jaką przykłada się do spraw dyscyplinarnych i karnych, w których w charakterze obwinionego lub skazanego występuje nauczyciel. W sposób jednoznaczny dyskredytują one pracownika pedagogicznego pozbawiając go prawa do pracy w tym zawodzie.

17 Zob. m.in.: wyrok Sądu Najwyższego z 20.02.2014 r., III PK 71/13, Legalis; wyrok Sądu Najwyższego z 22.01.2015 r., III PK 56/14, Legalis.

${ }_{18}$ Zob. m.in.: wyrok Sądu Najwyższego z 05.11.1998 r., I PKN 420/98, Legalis; wyrok Sądu Najwyższego z 11.09.2001 r., I PKN 610/00, Legalis.

19 Zob. m.in.: wyrok Sądu Najwyższego z 19.02.2000 r., II PKN 156/08, Legalis.

${ }^{20}$ Zob. m.in. wyrok Sądu Najwyższego z 22.09.2000 r., I PKN 29/00, Legalis. W tezie do przywołanego wyroku Sąd Najwyższy stwierdził, że „długotrwałe, dezorganizujące pracę w szkole nieobecności nauczyciela w pracy z powodu choroby mogą uzasadniać jego wybór do przeniesienia w stan nieczynny". Następnie w uzasadnieniu Sądu Najwyższego odniósł się do interesu szkoły i dobra uczących się w niej dzieci: „Interesowi szkoły, jako placówki kształcącej i wychowującej młodzież, nie może być przeciwstawiany socjalny i ekonomiczny interes nauczyciela, który już od kilku lat nie może wykonywać i nie wykonuje należących do niego zadań. Przeciwny punkt widzenia oznaczałby, że bez względu na cele szkoły oraz dobro dzieci i młodzieży należy chronić nauczyciela, od którego nie można oczekiwać świadczenia pracy".

${ }^{21}$ A. Barański, M. Szymańska, J. Rozwadowska-Skrzeczyńska, Karta Nauczyciela. Komentarz, s. 305.

${ }^{22}$ W szczególności chodzi o: prawomocne ukaranie w postępowaniu dyscyplinarnym karą dyscyplinarną zwolnienia z pracy oraz karą dyscyplinarną zwolnienia z pracy z zakazem przyjmowania ukaranego do pracy $\mathrm{w}$ zawodzie nauczyciela $\mathrm{w}$ okresie 3 lat od ukarania lub karą wydalenia z zawodu nauczyciela; prawomocne skazanie na kare pozbawienia praw publicznych albo prawa wykonywania zawodu; prawomocne skazanie za umyślne przestępstwo lub umyślne przestępstwo skarbowe. 


\section{Obowiązki nauczyciela jako pracownika}

W ramach stosunku pracy nauczyciel zobowiązany jest, jak każdy pracownik, wykonywać pracę sumiennie i starannie oraz stosować się do poleceń przełożonego, które dotyczą pracy, jeżeli nie są one sprzeczne z przepisami prawa lub umową o pracę. Za oczywiste standardy w zakresie jakości świadczonej pracy ustawodawca uznaje: przestrzeganie przez pracownika czasu pracy ustalonego w zakładzie pracy; przestrzeganie regulaminu pracy i ustalonego w zakładzie pracy porządku; przestrzeganie przepisów oraz zasad bezpieczeństwa i higieny pracy, a także przepisów przeciwpożarowych; dbanie o dobro zakładu pracy, chronienie jego mienia oraz zachowanie w tajemnicy informacji, których ujawnienie mogłoby narazić pracodawcę na szkodę; przestrzeganie tajemnicy określonej w odrębnych przepisach; przestrzeganie w zakładzie pracy zasad współżycia społecznego (art. 100 §2 k.p.).

Katalog podstawowych obowiązków nauczycieli zawarty został w KartaNauczU w art. 6. Przepis ten składa się z ogólnych sformułowań, których silnie aksjologiczne zabarwienie daje podstawy do traktowania ich w kategoriach klauzul generalnych. Jako takie wykorzystywane są jako ustawowe kryteria oceny pracy nauczyciela oraz pociągania go do odpowiedzialności dyscyplinarnej. Od nauczyciela oczekuje się rzetelnego realizowania zadań związanych z powierzonym mu stanowiskiem oraz podstawowymi funkcjami szkoły, przy czym w tego typu działaniach - zgodnie z brzmieniem art. 5 PrOświat - powinien kierować się dobrem uczniów, troską o ich zdrowie, postawę moralną i obywatelską z poszanowaniem godności osobistej ucznia. Pracownik pedagogiczny korzysta z władztwa zakładowego placówki, które oznacza podległość użytkownika zakładu administracyjnym aktom i poleceniom organów tegoż zakładu ${ }^{23}$. Tym samym, staje się on podmiotem władztwa pedagogicznego, które w relacji nauczyciel-uczeń narzuca uczniowi dyspozycyjność w zakresie nauczania i wychowania ${ }^{24}$. Wyraża się ona między innymi w podporządkowaniu poleceniom, podleganiu procedurze oceniania, klasyfikowania i promowania, podleganiu dyscyplinie i posłuchu, odnoszeniu się do nauczyciela z należytym szacunkiem. Z uwagi na asymetryczność stosunku wychowawczego uczniowi zapewnia się ochronę opartą na zasadzie dobra dziecka, wyznaczającej kierunek postępowania zgodny z najlepszym jego interesem. Na straży ochrony tegoż dobra stoi szereg podmiotów i instytucji, posiadających kompetencje do ingerowania w działalność całej placówki oświatowej lub pociągania do odpowiedzialności konkretnego na-

${ }^{23}$ M. Pilich, Ustawa o systemie oświaty, Warszawa 2015, s. 716.

${ }^{24}$ J. Homplewicz, Kierunki rozwoju prawa szkolnego w Polsce, [w:] Prawo. Administracja. Gospodarka. Księga ku czci Profesora Ludwika Bara, red. J. Łętowski, J.P. Pruszyński, Wrocław 1983, s. 134. 
uczyciela (są to m.in. organ nadzoru pedagogicznego, komisja dyscyplinarna, sąd rodzinny, czy prokuratura).

W przywołanym art. 6 KartaNauczU postulat podejmowania pedagogicznych działań realizujących powyższą zasadę wypełniony jest kolejnymi treściami: „wspierania każdego dziecka w jego rozwoju”, „kształcenia i wychowywania młodzieży w umiłowaniu Ojczyzny, w poszanowaniu Konstytucji Rzeczypospolitej Polskiej, w atmosferze wolności sumienia i szacunku dla każdego człowieka”, , dbania o kształtowanie u uczniów postaw moralnych i obywatelskich, zgodnie z ideą demokracji, pokoju i przyjaźni (...)". Uzupełnieniem katalogu obowiązków nauczyciela jest regulacja dotycząca czasu jego pracy, zawarta w art. 42 KartaNauczU. Wprowadza ona regułę 40-godzinnego tygodnia pracy, w ramach którego to wymiaru nauczyciel: 1) realizuje zajęcia dydaktyczne, wychowawcze i opiekuńcze bezpośrednio z uczniami lub wychowankami albo na ich rzecz, zgodnie z rozkładem przewidzianym dla danego stanowiska i typu/rodzaju placówki; 2) prowadzi inne zajęcia i podejmuje czynności wynikające z zadań statutowych; 3) przygotowuje się do zajęć i doskonali zawodowo.

Pierwsza kategoria obowiązków pracowniczych nauczyciela obejmuje zajęcia dydaktyczne, wychowawcze i opiekuńcze, prowadzone bezpośrednio z uczniami lub wychowankami albo na ich rzecz. Tygodniowy obowiązkowy rozkład tego typu zajęć składa się na nauczycielskie pensum, którego wymiar determinują zajmowane stanowisko oraz typ placówki. W tej grupie znajdują się obowiązkowe i dodatkowe zajęcia edukacyjne, zajęcia świetlicowe oraz zajęcia z zakresu pomocy psychologiczno-pedagogicznej (w tym rozwijające uzdolnienia, rozwijające umiejętności uczenia się, zajęcia dydaktyczno-wyrównawcze, specjalistyczne: korekcyjno-kompensacyjne, logopedyczne, rozwijające kompetencje emocjonalno-społeczne i inne zajęcia o charakterze terapeutycznym, zajęcia związane z wyborem kierunku kształcenia i zawo$\mathrm{du}$ ). Jeśli przydzielone nauczycielowi godziny tego typu zajęć przekraczają tygodniowy obowiązkowy wymiar godzin ustalony dla danego stanowiska, stanowią one godziny ponadwymiarowe uprawniające pracownika do dodatkowego wynagrodzenia. Przydzielane są one przez dyrektora zgodnie z kwalifikacjami nauczyciela do maksymalnej wysokości 1/2 tygodniowego obowiązkowego wymiaru zajęć pod warunkiem jego akceptacji. Zgoda nauczyciela nie jest jednak wymagana, jeśli przydział ten nie przekracza 1/4 wymiaru.

Do kategorii tak zwanych innych niż dydaktyczne, wychowawcze i opiekuńcze zajęć prowadzonych bezpośrednio z uczniami albo na ich rzecz zalicza się między innymi: udzielanie konsultacji uczniom i ich rodzicom, udział w zebraniach rady pedagogicznej, udział w pracach zespołów przedmiotowych, sprawowanie funkcji opiekuna podczas wycieczki szkolnej lub zielonej 
szkoły, przygotowanie gazetki szkolnej, prowadzenie wywiadówki, utrzymywanie kontaktu $\mathrm{z}$ rodzicami $\mathrm{w}$ innych formach, uczestnictwo $\mathrm{w}$ przeprowadzaniu egzaminu ósmoklasisty, egzaminu potwierdzającego kwalifikacje zawodowe, egzaminu maturalnego (z wyjątkiem części ustnej). Tego typu aktywności mają bardzo zróżnicowany charakter i tworzą w zasadzie katalog otwarty, a ich wspólną cechą jest wywodzenie się z zapisów statutowych skorelowanych z podstawowymi funkcjami placówki oświatowej. Statut szkoły stanowi najważniejszy akt prawa wewnątrzszkolnego, a do jego podstawowych treści należy wskazanie między innymi: celów i zadań szkoły oraz sposobów ich wykonania; zakresu zadań nauczycieli oraz sposobów i form ich wykonania dostosowanych do wieku i potrzeb uczniów oraz warunków środowiskowych szkoły; organizacji współdziałania z poradniami psychologiczno-pedagogicznymi i innymi instytucjami działającymi na rzecz rodziny, dzieci i młodzieży; organizacji i form współdziałania szkoły z rodzicami w zakresie nauczania, wychowania, opieki i profilaktyki (art. 42 KartaNauczU czy art. 98 PrOświat). Omawiana kategoria obowiązków pracowniczych nie uprawnia nauczyciela do dodatkowego wynagrodzenia i może wiązać się $\mathrm{z}$ angażowaniem go $\mathrm{w}$ czasochłonne przedsięwzięcia, znacznie przekraczające ustawowe normy tygodniowego wymiaru pracy.

O przydziale poszczególnym nauczycielom innych zajęć i czynności wynikających z zadań statutowych szkoły decyduje dyrektor, wydając stosowne polecenia służbowe. Wykonywanie przez pracownika poleceń pracodawcy jest jego podstawowym obowiązkiem wynikającym ze stosunku pracy (,wykonywanie pracy określonego rodzaju na rzecz pracodawcy i pod jego kierownictwem"). Stanowi wyraz podporządkowania, odróżniający ten rodzaj relacji od stosunków cywilnoprawnych dotyczących świadczenia określonych usług. W ramach pracowniczego podporządkowania pracodawca może wydawać polecenia dotyczące sposobu wykonywania pracy, a $\mathrm{w}$ przewidzianych prawem przypadkach żądać wykonania pracy innej niż umówiona (w przypadkach uzasadnionych potrzebami pracodawcy na okres do 3 miesięcy w roku kalendarzowym, jeśli nie powoduje to obniżenia wynagrodzenia i odpowiada kwalifikacjom pracownika, co wynika z art. 42 $\$ 4$ k.p.), bądź w granicach przekraczających czasowy wymiar zatrudnienia (czyli praca $w$ godzinach nadliczbowych dopuszczalna $w$ przypadku szczególnych potrzeb pracodawcy, co wynika z art. 151 \$1 k.p.). Pracownik nie jest uprawniony do kontroli i kwestionowania słuszności polecenia, a za jego niewykonanie ponosi on odpowiedzialność, chociażby było ono obiektywnie wadliwe $^{25}$. W prawie pracy przewidziane sa jednak dwa przypadki, kiedy to

${ }^{25}$ J. Skoczyński, D. Dzienisiuk, Rozdział I. Obowiązki pracodawcy, [w:] Kodeks pracy. Komentarz, s. 653. 
polecenie wydane przez pracodawcę nie ma charakteru wiążącego i pracownik zwolniony jest z obowiązku jego wypełnienia (art. $100 \$ 1$ k.p.). Pierwsza sytuacja dotyczy poleceń wykraczających poza granice podporządkowania pracownika; drugi przypadek to polecenia, których wykonanie prowadziłoby do naruszenia obowiązujących przepisów prawa. Jeśli więc wydane przez pracodawcę polecenie nie mieści się w zakresie obowiązków wynikających z umowy o pracę oraz podważa zasadę legalności, pracownik nie jest nim związany i w przypadku odmowy wykonania nie musi obawiać się poniesienia negatywnych konsekwencji za uchylanie się od obowiązków pracowniczych ${ }^{26}$. W okolicznościach funkcjonowania placówki oświatowej odmowa nauczyciela może wynikać na przykład z przydzielenia nauczycielowi w ramach zajęć statutowych obowiązków niepedagogicznych. Przede wszystkim jednak nauczyciel nie powinien bezkrytycznie wykonywać poleceń dyrektora, jeśli są bezprawne lub których realizacja wiąże się z kolizją z innymi obowiązkami, na przykład związanymi z zapewnieniem uczniom bezpieczeństwa ${ }^{27}$. Priorytetowe traktowanie obowiązków opiekuńczych pracownika pedagogicznego pozostaje w zgodzie ze specyfiką funkcjonowania zakładu pracy, jakim jest szkoła i wyznaczającą rytm jej pracy klauzulą dobra dziecka.

Ostatnie z zadań wyartykułowanych w art. 42 ust. 3 KartaNauczU stanowi element dążenia do pełni własnego rozwoju osobowego i wymaga od nauczyciela uwzględnienia zapotrzebowania placówki na pracownika o określonych kwalifikacjach („,doskonalenie zawodowe zgodne z potrzebami szkoły"). Ustalanie porządku w ramach procedury dokształcania kadry pedagogicznej danej placówki leży w zakresie kompetencji stanowiących rady pedagogicznej (art. 70 ust. 1 PrOświat), podejmującej uchwały w sprawie organizacji doskonalenia zawodowego. Zadania dyrektora w tym obszarze wiążą się z opracowaniem planu doskonalenia zawodowego nauczycieli oraz - adresowanego do konkretnego nauczyciela - indywidualnego planu wspomagania, obejmującego konsultacje, lekcje koleżeńskie, szkolenia. Tego typu działania podejmuje dyrektor $w$ ramach sprawowanego nadzoru pedagogicznego. Mieszczą się one w zakresie wspomagania nauczycieli w reali-

${ }^{26}$ Jeśli jednak pracodawca podejmie decyzję o rozwiązaniu umowy o pracę z powodu odmowy wykonania polecenia, pracownik może wystąpić do sądu pracy z roszczeniem o uznanie wypowiedzenia za bezskuteczne, ewentualnie z roszczeniem o przywrócenie do pracy (art. 45 $\S 1$ k.p.). W postępowaniu sądowym przedmiotem badania będzie wówczas zgodność polecenia służbowego z wymienionymi wyżej kryteriami.

${ }^{27} \mathrm{~W}$ takim kontekście należy interpretować rozstrzygnięcie Sądu Najwyższego zawarte w wyroku z 05.05.1975 r., II CR 153/75, Legalis. Sąd Najwyższy podkreślił, iż „w sytuacji, gdy zachowanie uczniów narusza obowiązujące zasady - lub stwarza niebezpieczeństwo ich naruszenia - nauczyciel sprawujący nadzór nad powierzonymi mu uczniami, winien w razie kolizji ciążach na nim w tym samym czasie zadań typu nadzorczego z zadaniami typu administracyjnego, dawać pierwszeństwo zadaniom nadzorczym dopóki nie zapewni warunków zapobiegających naruszeniu dyscypliny przez uczniów, mogącemu wywołać szkodę". 
zacji ich zadań, w szczególności poprzez: diagnozę pracy szkoły; planowanie działań rozwojowych, w tym motywowanie nauczycieli do podwyższania swoich kwalifikacji; prowadzenie działań rozwojowych, w tym organizowanie szkoleń i narad ${ }^{28}$.

Jak z powyższego wynika, w zakresie relacji na poziomie stosunków pracy łączących dyrektora z poszczególnymi nauczycielami jest on podmiotem dominującym, wyposażonym we władztwo wynikające z podległości służbowej, do której zobligowani są pracownicy pedagogiczni, podobnie jak cały zatrudniany w szkole personel. Odrębny charakter relacji łączy dyrektora z całym gronem pedagogicznym, tworzącym drugi główny organ placówki oświatowej, czyli radę pedagogiczną. W jej skład wchodzą wszyscy nauczyciele zatrudnieni w danej placówce oraz dyrektor, którego rola w warunkach kolegialnego obradowania oraz demokratycznego podejmowania decyzji w formie uchwał sprowadza się do przewodniczenia posiedzeniom rady. Funkcja ta pozbawiona jest w zasadzie arbitralności i ogranicza się do przygotowania (czyli określenia terminu i proponowanego porządku dziennego) i prowadzenia zebrań (czyli udzielania obecnym głosu, formułowania treści projektów uchwał, zarządzania głosowania, obwieszczania zebranym podjętego rozstrzygnięcia) oraz zawiadamiania członków rady o terminie i porządku tych zebrań (art. 69 ust. 4-6 PrOświat). Wskazane wyżej czynności mają charakter organizacyjno-porządkowy i z punktu widzenia specyfiki organu, jaką jest kolegialność rady pedagogicznej ich podjęcie dla sprawnego funkcjonowania organu wydaje się konieczne. Dodatkowo dyrektor zobligowany został do systematycznego (nie rzadziej niż 2 razy w roku szkolnym) przedkładania ogólnych wniosków wynikających ze sprawowanego nadzoru pedagogicznego i informacji o działalności placówki. Przedstawianie wniosków ma charakter wyłącznie informacyjny i nie wiąże się z koniecznością głosowania w celu ich zatwierdzenia czy też udzielania dyrektorowi absolutorium.

Funkcja przewodniczącego rady pedagogicznej przynależy z mocy prawa wyłącznie dyrektorowi, co nie wyklucza przekazania jej pełnienia wicedyrektorowi lub innemu nauczycielowi zajmującemu stanowisko kierownicze. Dotyczy to jednak sytuacji wyjątkowych, wynikających z przemijającej przeszkody, co oznacza, że statut szkoły nie może modyfikować dyrektorskich prerogatyw $\mathrm{w}$ tym zakresie ${ }^{29}$. Jako przewodniczący, dyrektor korzysta $\mathrm{z}$ prawa zwołania posiedzenia rady, przy czym prawo przewiduje okoliczności, kiedy takie zebranie jest obligatoryjne (przed rozpoczęciem roku szkolnego, w każdym semestrze $\mathrm{w}$ związku z zatwierdzeniem wyników klasyfikowa-

${ }^{28}$ Z. Rudzińska, Nadzór pedagogiczny w przedszkolu i szkole - praktyczne zastosowanie nowych przepisów, Warszawa 2019, s. 31.

${ }^{29}$ Rozstrzygnięcie nadzorcze Wojewody Wrocławskiego z 15.07.1998 r., ON.II.0914/27/98, OwSS 1998, nr 4, poz. 114. 
nia i promowania uczniów, po zakończeniu roku szkolnego). W pozostałych przypadkach zebrania rady mają charakter fakultatywny i odbywają się „W miarę bieżących potrzeb" (np. W celu ustalenia sposobu postępowania w nowych dla szkoły okolicznościach, przedyskutowania ważnych z punktu widzenia realizowanych zadań spraw, ujawnionych problemów wychowawczych czy konfliktów, organizacji rocznic), o czym decyduje przewodniczący. Jeśli jednak z wnioskiem o zwołanie zebrania rady wystąpi organ sprawujący nadzór pedagogiczny, organ prowadzący, rada szkoły lub $1 / 3$ członków rady pedagogicznej jest on dla dyrektora wiążący. Może więc dochodzić do sytuacji, kiedy to dyrektor $\mathrm{z}$ inicjatywy reprezentatywnej grupy przedstawicieli grona pedagogicznego, a więc swoich pracowników, zobligowany zostanie do zwołania i przeprowadzenia zebrania rady. Taka sytuacja wskazuje na pozbawienie dyrektora $\mathrm{w}$ relacji $\mathrm{z}$ tym organem przymiotu władztwa i uznaniowości.

Świadczą o tym również kompetencje rady odnoszące się do realizacji zadań statutowych szkoły. Dzieli się je na kompetencje stanowiące oraz opiniodawcze. Pierwszą grupę stanowią działania, których podjęcie przez radę warunkuje określone skutki prawne ${ }^{30}$. Są to uchwały podejmowane w związku z: zatwierdzaniem planów pracy szkoły lub placówki po zaopiniowaniu przez radę szkoły lub placówki; klasyfikacją i promowaniem uczniów; organizacją eksperymentów pedagogicznych w szkole lub placówce, po zaopiniowaniu ich projektów przez radę szkoły lub placówki oraz radę rodziców; organizacją doskonalenia zawodowego nauczycieli szkoły lub placówki; wyrażaniem opinii w sprawach skreślenia z listy uczniów; ustalaniem sposobu wykorzystania wyników nadzoru pedagogicznego. Jak wynika z powyższego zestawienia, aktywność członków rady sprowadza się do współuczestnictwa w zarządzaniu jednostką organizacyjną, w której są zatrudnieni ${ }^{31}$. Ma to miejsce w podstawowych obszarach jej funkcjonowania poprzez przypisanie radzie wyłącznych kompetencji przy organizacji procesu dydaktyczno-wychowawczego (takich jak procedura klasyfikowania i promowania uczniów ${ }^{32}$, czy rozstrzyganie o działaniach innowacyjnych oraz eksperymentach peda-

30 M. Pyter, A. Balicki, Prawo oświatowe. Komentarz, Warszawa 2017, s. 239-240.

31 M. Pilich, Ustawa o systemie oświaty. Komentarz, Warszawa 2015, s. 729.

${ }^{32} \mathrm{~W}$ zakresie tej kompetencji stanowiącej rady pedagogiczne nastąpiły w ostatnim czasie istotne zmiany legislacyjne. Otóż Ustawą z 25.04.2019 r. o zmianie ustawy o systemie oświaty i ustawy - Prawo oświatowe (DzU z 2019 r., poz. 761) wprowadzono do PrOśw art. 73a, na mocy którego dyrektor szkoły stał się organem odpowiedzialnym za dokonanie klasyfikacji i promocji uczniów w sytuacji, gdy rada pedagogiczna nie podejmie w tej sprawie stosownej uchwały. Zgodnie z uzasadnieniem do powyższej nowelizacji zmiana przepisów - pozbawiająca rady wyłącznej kompetencji w przeprowadzeniu tej podstawowej dla procesów dydaktycznych procedury - miała na celu ochronę prawa do nauki na wypadek gdyby organ ten, z różnych przyczyn, nie wykonywał należących do niego obowiązków. 
gogicznych wdrażanych w placówce), ale również poprzez zobowiązanie jej do współdziałania z radą rodziców i radą szkoły (przede wszystkim w ramach uchwalania programu wychowawczo-profilaktycznego czy przygotowania projektu statutu lub jego zmian).

Szczególnym uprawnieniem dyrektora $\mathrm{w}$ relacjach $\mathrm{z}$ radą pedagogiczną jest wstrzymanie wykonania uchwał rady w przypadku uznania ich sprzeczności z przepisami prawa, jednak o ewentualnym uchyleniu uchwały decyduje organ sprawujący nadzór pedagogiczny po zasięgnięciu opinii organu prowadzącego szkołę. Natomiast, w przypadku rozstrzygnięcia o utrzymaniu uchwały w mocy, staje się ona formalnie wiążąca i dyrektor jest obowiązany ją wykonać. Kompetencja dyrektora, polegająca na zawieszaniu uchwał, ma więc ograniczoną moc kontrolną, służącą wyłącznie pełniejszej realizacji zasady legalizmu działania organów placówki oświatowej. Kontrolna rola dyrektora, niewyartykułowana wprost w KartaNauczU czy PrOświat, wynika również z obostrzeń prawnych adresowanych do osób biorących udział w zebraniu rady pedagogicznej (art. 73 ust. 3 PrOświat). Otóż, uczestnicy zebrania (dotyczy to przede wszystkim nauczycieli, ale również innych obecnych osób) są zobowiązani do nieujawniania spraw poruszanych w trakcie jej przebiegu, jeśli mogłyby one naruszać dobra osobiste uczniów, ich rodziców, a także nauczycieli i innych pracowników szkoły. Przywołany przepis odnosi się do tajemnicy rady pedagogicznej, stanowiącej instytucję charakterystyczną dla prawa oświatowego ${ }^{33}$, ale interpretowaną na podstawie Kodeksu cywilnego ${ }^{34}$. Otóż, zgodnie z art. 23 kodeksu, wśród dóbr osobistych, czyli wartości szczególnie doniosłych dla określonej osoby, z którą ta wartość jest w sposób ścisły związana, należą w szczególności: zdrowie, wolność, cześć, swoboda sumienia, nazwisko lub pseudonim, wizerunek, tajemnica korespondencji, nietykalność mieszkania, twórczość naukowa, artystyczna, wynalazcza i racjonalizatorska. W judykaturze ten otwarty katalog poszerzony został między innymi o życie prywatne, $\mathrm{w}$ tym również rodzinne ${ }^{35}$. Celem wprowadzenia do PrOświat przepisu odwołującego się do ochrony dóbr osobistych jest przeciwdziałanie sytuacjom, kiedy to dzięki udziałowi w zebraniu rady uczestnik takiego zebrania poprzez publiczne ujawnianie

${ }^{33} \mathrm{~W}$ literaturze zwraca się uwagę na deficyty w zakresie regulacji problematyki poufności w pracy nauczyciela i związanej z nią tajemnicy zawodowej. Por. K. Roszewska, Tajemnica zawodowa nauczyciela, MoP, 2014, 24, s. 1331-1335.

${ }^{34}$ Ustawa z 23.04.1964 r., t.j. DzU z 2019 r. poz. 1145 ze zm.

${ }^{35}$ Jako przykład warto przytoczyć wypowiedź zawartą w uzasadnieniu do wyroku Sądu Najwyższego z 26.05.2017 r., I CSK 557/16, Legalis. Zdaniem Sądu, „sferą życia prywatnego są objęte informacje dotyczące życia rodzinnego i stosunków małżeńskich. Informacje te odnoszą się najogólniej do sytuacji jednostki w rodzinie, jej relacji i więzi z pozostałymi członkami rodziny, sposobu spędzania czasu w rodzinie, tajemnic rodzinnych, przeżywania i pielęgnowania rodzinnych uroczystości i zwyczajów". 
określonych informacji stwarzałby zagrożenie naruszenia lub naruszał dobra dziecka, rodziców lub pracowników placówki. Z racji pełnienia funkcji przewodniczącego dyrektor prowadzi posiedzenia rady, dbając o nienaruszanie przez obecnych porządku zebrania i przepisów prawa. Powinien więc zadbać o wiedzę uczestników na temat tajemnicy rady pedagogicznej, a w sytuacji pojawiających się $\mathrm{w}$ trakcie zebrania naruszeń może wykorzystać narzędzie w postaci odmowy udzielenia głosu lub jego odebrania (kwestie te reguluje regulamin działalności rady). Kiedy osobą ingerującą $\mathrm{w}$ dobra osobiste jest nauczyciel, dyrektor powinien zawiadomić rzecznika dyscy plinarnego. W takiej sytuacji nauczyciel, niezależnie od odpowiedzialności cywilnej, może ponieść odpowiedzialność dyscyplinarną, bowiem zachowania naruszające dobra osobiste, zwłaszcza uczniów, są sprzeczne z podstawowymi jego obowiązkami (kierowanie się dobrem ucznia i poszanowanie jego godności osobistej), ale co więcej - przeczą godności wykonywanego zawodu.

O złożoności relacji pomiędzy dyrektorem a radą pedagogiczną świadczy ponadto uprawnienie rady do występowania $\mathrm{z}$ wnioskiem o odwołanie nauczyciela ze stanowiska dyrektora. W takim przypadku organ uprawniony do odwołania (organ prowadzący) powinien przeprowadzić postępowanie wyjaśniające i powiadomić o jego wyniku radę pedagogiczną w ciągu 14 dni od otrzymania wniosku. W jego trakcie przedmiotem badania jest zaistnienie jednej w przewidzianych w PrOświat przesłanek legitymujących organ prowadzący do podjęcia tej radykalnej decyzji (art. 66). Przesłankę badaną w sytuacji inicjatywy rady stanowi wystąpienie tak zwanego "przypadku szczególnie uzasadnionego", przy czym jej zaistnienie może nastręczać trudności interpretacyjne. Z pewnością, zwrot „szczególnie” zawęża zastosowanie przedmiotowej regulacji do przypadków zupełnie wyjątkowych, nadzwyczajnych i nagłych, kiedy organ prowadzący ma prawo ocenić, czy dalsze kierowanie szkołą stanowi istotne zagrożenie dla jej funkcjonowania lub z jakichkolwiek innych obiektywnie ważnych przyczyn jest nie do przyjęcia ${ }^{36}$.

${ }^{36}$ Na temat zawężającej wykładni przesłanki „przypadków szczególnie uzasadnionych” wypowiedział się Naczelny Sąd Administracyjny w wyroku z 06.08.2015 r., I OSK 901/15, popierając stanowisko rozpatrującego przedmiotową sprawę Wojewódzkiego Sądu Administracyjnego w Warszawie (wyrok z 30.12.2014 r., II SA/Wa 929/14). Zdaniem przywołanych sądów administracyjnych wspomniany zwrot „zawęża pole zastosowania tego przepisu do sytuacji zupełnie wyjątkowych, nadzwyczajnych, kiedy organ odwołujący ma pełne prawo ocenić, że dalsze kierowanie szkołą, placówką lub jej wyodrębnioną organizacyjnie częścią stanowi istotne zagrożenie dla osiągnięcia jej celów lub z jakichkolwiek innych, obiektywnie ważnych względów jest nie do przyjęcia. Przyczyną odwołania w tym trybie mogą być takie zaniedbania obowiązków dyrektora, które mogą prowadzić do destabilizacji funkcjonowania szkoły, tj. realizacji jej zadań w zakresie nauczania i wychowania. Nie każde naruszenie prawa przez dyrektora jest wystarczające do zastosowania tej formy odwołania, a jedynie takie, które powoduje konieczność natychmiastowego zaprzestania spełniania przezeń tej funkcji z uwagi na zagrożenie dla interesu publicznego."; http:/ / orzeczenia.nsa.gov.pl [dostęp: 17.01.2020]. 


\section{Pociąganie nauczyciela do odpowiedzialności w ramach stosunku pracy}

Problematyka odpowiedzialności prawnej nauczycieli jest złożona, bowiem szeroki wachlarz ich obowiązków stanowi przedmiot regulacji norm prawnych wywodzących się z różnych gałęzi prawa (kodeksu pracy, kodeksu cywilnego, Karty Nauczyciela, kodeksu karnego). Jednak funkcjonowanie nauczycieli w warunkach specyficznych dla szkoły jako zakładu pracy implikuje zastosowanie przede wszystkim regulacji dotyczących odpowiedzialności porządkowej oraz dyscyplinarnej. Pomiędzy tymi rodzajami odpowiedzialności istnieje zasadnicza różnica. Otóż, k.p. w sposób wyczerpujący wymienia przesłanki naruszenia przepisów porządkowych, zaś KartaNauczU w kwestii postępowania dyscyplinarnego posługuje się ogólnymi sformułowaniami („uchybienie godności zawodu nauczyciela”, „uchybienie obowiązkom, o których mowa w art. 6"). Może to rodzić wątpliwości interpretacyjne $\mathrm{w}$ zakresie rozstrzygania o tym, z jaką odpowiedzialnością należy wiązać naruszenie, którego sprawcą jest nauczyciel. Zasadniczo przyjmuje się, że zachowanie nauczyciela, któremu nie można przypisać konkretnego przekroczenia porządkowego należy uznać za przewinienie dyscyplinarne ${ }^{37}$. Ukaranie nauczyciela karą porząd kową w wyniku uznania, że uchybił on porządkowi pracy, stanowi negatywną przesłankę pociągania go do odpowiedzialności dyscyplinarnej (art. 85 ust. 4 pkt 2 KartaNauczU). Dyrektor ograniczony jest jednak $\mathrm{w}$ obszarze uruchamiania odpowiedzialności pracowniczej regulacją art. 75 ust. 2a KartaNauczU, formułującą zakaz wymierzania kar porządkowych za popełnienie czynu naruszającego prawa i dobra dziecka. $\mathrm{O}$ takim zdarzeniu dyrektor powinien w ciągu 3 dni roboczych od powzięcia wiadomości o popełnieniu czynu zawiadomić rzecznika dyscyplinarnego, który po przeprowadzeniu postępowania wyjaśniającego podejmuje decyzję o przekazaniu sprawy komisji dyscyplinarnej z wnioskiem o ukaranie sprawcy karą dyscyplinarną.

\section{Odpowiedzialność porządkowa nauczycieli}

Nauczyciel jako pracownik, do którego zastosowanie mają przepisy prawa pracy podlega odpowiedzialności porządkowej, stanowiącej rodzaj odpowiedzialności pracowniczej ${ }^{38}$. Mówi o tym wprost KartaNauczU w art. 75

37 T. Konarska, Szkolne prawo pracy. Poradnik dyrektora szkoty, Warszawa 2019, s. 368.

${ }^{38}$ Kategoria odpowiedzialności pracowniczej jest ogólna i oprócz zagadnień związanych z naruszeniem przez pracownika norm wyznaczających organizację i porządek zakładu pracy (odpowiedzialność porządkowa), obejmuje również odpowiedzialność materialną ponoszoną w związku z zawinionym wyrządzeniem pracodawcy szkody. Ten drugi rodzaj odpowiedzialności pracowniczej regulowany jest $\mathrm{w}$ art. 114-127 k.p. i nie stanowi przedmiotu rozważań niniejszego opracowania. 
ust. 2, nakazując w sytuacjach uchybień przeciwko porządkowi pracy wymierzenie nauczycielowi kary porządkowej zgodnie z k.p. Pracownicza odpowiedzialność porządkowa jest jednym z rodzajów zobowiązaniowej odpowiedzialności pracownika za niewykonanie lub nienależyte wykonanie zobowiązania ${ }^{39}$. Z uwagi na krótki okres zacierania się (upływu czasu niezbędnego do uznania za niebyłą) orzeczonej kary porządkowej, odpowiedzialność ta traktowana jest jako „łagodny sposób zwrócenia pracownikowi uwagi na brak dyscypliny w pracy" ${ }^{\prime 4} \mathrm{i}$ środek o przede wszystkim wychowawczym charakterze. Jej uruchomienie nie jest warunkowane powstaniem po stronie pracodawcy szkody, natomiast przesłankę konieczną stanowi wina pracownika, co oznacza, że ten rodzaj odpowiedzialności nie ma charakteru obiektywnego.

Odpowiedzialność porządkowa stanowi konsekwencję dokonania naruszeń tylko określonych obowiązków pracowniczych (a więc nie wszystkich). Są to czyny naruszające organizację i porządek pracy, przepis bhp oraz przepisy przeciwpożarowe. Co więcej, pracownik może zostać ukarany tylko takimi karami porządkowymi, jakie zostały wymienione w art. 108 k.p., czyli upomnieniem, naganą albo karą pieniężną. Szczególne ograniczenia w zakresie zastosowania dotyczą kary pieniężnej, uruchamianej wyłącznie w przypadkach naruszeń przepisów bhp, przepisów przeciwpożarowych, opuszczenia pracy bez usprawiedliwienia, stawienia się do pracy w stanie nietrzeźwości lub spożywania alkoholu $\mathrm{w}$ czasie pracy. Ponadto, przepisy pracy wprowadzają limity wysokości nakładanej na pracownika kary pieniężnej ${ }^{41}$. K.p. nie nakłada na pracodawcę obowiązku stosowania gradacji kar, w związku z czym pracownik może od razu zostać ukarany karą nagany. Przepisy wskazują jedynie przesłanki, jakie pracodawca powinien w szczególności wziąć pod uwagę wymierzając karę (są nimi: rodzaj naruszenia, stopień winy pracownika, jego dotychczasowy stosunek do pracy). Istotnym ograniczeniem jest jednak niemożność wymierzenia za jedno wykroczenie kilku kar jednocześnie. Przepisy k.p. w art. 109-113 szczegółowo regulują problematykę warunków zastosowania kar porządkowych oraz procedurę pociągania pracownika do tej odpowiedzialności (w tym: zawiadomienie pracownika; wniesienie przez niego sprzeciwu; tryb odwoławczy inicjowany poprzez wniesienie sprzeciwu i pozwu o uchylenie kary; zatarcie kary). Istotną właściwością odpowiedzialności porządkowej jest to, że pracodawca nie ma obowiązku jej

${ }^{39}$ J. Skoczyński, D. Dzienisiuk, Rozdział VI. Odpowiedzialność porządkowa pracowników [w:] Kodeks pracy, s. 719.

${ }^{40}$ T. Konarska, Szkolne prawo pracy, s. 368.

${ }^{41}$ Kara pieniężna za jedno przekroczenie nie może być wyższa od jednodniowego wynagrodzenia pracownika, a łączna wysokość kar za wszystkie naruszenia pracownicze nie może przekraczać dziesiątej części wynagrodzenia przypadającego pracownikowi do wypłaty po dokonaniu stosownych potrąceń. 
uruchamiania, jednak podejmując taką decyzję, jest związany treścią powyższych przepisów, bowiem zawierają one normy bezwzględnie obowiązujące. Przekroczenie wskazanych regulacji powoduje nieważność postanowień pracodawcy (nie rodzą one więc skutków prawnych).

Odpowiedzialność porządkowa dotyczy nauczycieli zatrudnionych na podstawie umowy o pracę oraz mianowania, a także pozostałych pracowników zatrudnionych w szkole. Stanowi ona konsekwencję niewywiązywania się tych osób z zadań określonych szczegółowo w wewnątrzzakładowych aktach w postaci: regulaminu pracy, statutu szkoły, poszczególnych procedur, czy dyrektorskich zarządzeń. O tym, czy w danym przypadku nastąpiło naruszenie obowiązków pracowniczych oraz czy i jaka kara porządkowa ma być zastosowana decyduje dyrektor szkoły. W ramach uchybień pracowniczych nauczyciel może zostać ukarany, w szczególności za niewykonywanie lub niewłaściwe wykonywanie obowiązków w postaci: starannego przygotowywania się do zajęć dydaktycznych i ich sumiennego prowadzenia; przestrzegania czasu pracy ustalonego w szkole poprzez realizowanie zajęć dydaktycznych i wychowawczych zgodnie z rozkładem zajęć i grafikiem dyżurów; przestrzegania regulaminu pracy i ustalonego w szkole porządku, także poprzez wykonywanie poleceń dyrektora zgodnych z prawem i zakresem obowiązków wynikających z zajmowanego stanowiska; przestrzegania przepisów oraz zasad bezpieczeństwa i higieny pracy, a także przepisów przeciwpożarowych, w szczególności troski o bezpieczeństwo uczniów i udzielanie pierwszej pomocy; dbałości o dobre imię szkoły; przestrzegania tajemnicy rady pedagogicznej oraz zachowania dyskrecji w sprawach ucznia i jego sytuacji rodzinnej; przestrzegania zasad współżycia społecznego.

Kluczowe znaczenie dla organizacji i porządku pracy na terenie placówki oświatowej ma regulamin pracy. Wprowadzenie tego zakładowego źródła pracy jest uprawnieniem, a niekiedy obowiązkiem dyrektora wynikającym z art. 104 k.p. ${ }^{42}$ Powinien on również zadbać o zbiorowe podanie treści regulaminu do wiadomości pracowników (w wybranej przez siebie formie) oraz o zapoznanie z nim każdego nowo przyjętego pracownika do pracy. Należy przy tym pamiętać, że zapoznanie nie jest równoznaczne z podaniem do wiadomości, bowiem $w$ ramach tej czynności dyrektor powinien zadbać o wyjaśnienie pracownikowi wynikających z regulaminu konsekwencji dla procesu pracy ${ }^{43}$. Z punktu widzenia specyfiki organizacji szkoły wśród ustaleń regulaminu pracy (art. $104^{1}$ k.p.) wyróżnić należy: organiza-

${ }^{42}$ Od tego obowiązku zwolnieni są ci pracodawcy, którzy zatrudniają mniej niż 50 pracowników lub gdy w danym zakładzie pracy mają zastosowanie ustalenia zawarte w układzie zbiorowym pracy.

${ }^{43}$ T. Komorowski, J. Pielachowski, Dyrektor szkoty, s. 103. 
cję pracy ( $\mathrm{w}$ tym zależności między pracownikami w procesie pracy, czyli: określenie, kto komu podlega $\mathrm{w}$ procesie pracy; jakie kompetencje przysługują pracownikom zatrudnionym na stanowiskach kierowniczych; jakie środki dyscyplinujące mogą być przez nich stosowane wobec pracowników podporządkowanych; miejsca świadczenia pracy ${ }^{44}$ ); warunki przebywania na terenie zakładu pracy w czasie pracy i po jej zakończeniu; obowiązki pracowników dotyczące bezpieczeństwa i higieny pracy oraz ochrony przeciwpożarowej; inne zadania mieszczące się w pojemnym katalogu innych praw i obowiązków pracodawcy i pracowników wynikających z organizacji pracy. Dyrektor może wprowadzić do regulaminu pracy szereg innych regulacji, które, z jego punktu widzenia, są istotne dla skutecznej realizacji zadań powierzonych placówce oświatowej. Jedynym warunkiem ograniczającym go jest zgodność regulaminowych ustaleń z innymi regulacjami prawa pracy (art. 9 k.p.).

Wśród warunków przebywania nauczycieli na terenie zakładu pracy regulamin powinien uwzględniać uprawnienie każdego pracownika mającego obowiązek wykonywania pracy co najmniej przez sześć godzin dziennie $\mathrm{w}$ postaci pracowniczego prawa do przerwy w pracy w wymiarze co najmniej 15 minut (art. 134 k.p.). Co prawda przepis odnosi się do kategorii dobowego wymiaru czasu pracy, która w przypadku pracy osób objętych KartaNAuczU nie ma zastosowania, to jednak dyrektora nie zwalnia to $\mathrm{z}$ ogólnych obowiązków wynikających z norm chroniących zdrowie pracownika. Kiedy warunki pracy nie odpowiadają przepisom bezpieczeństwa i higieny pracy oraz stwarzają bezpośrednie zagrożenie dla zdrowia i życia pracownika albo gdy wykonywana przez niego praca grozi takim niebezpieczeństwem innym osobom, pracownik ma prawo powstrzymać się od wykonywania pracy, zawiadamiając o tym niezwłocznie przełożonego (art. 210 §1 k.p.). Jeśli więc po stronie pracownika zaistniały podstawy uzasadniające jego decyzję o powstrzymaniu się od świadczenia pracy i poinformował o tym przełożonego $^{45}$, wówczas zaniechanie nie stanowi naruszenia dyscypliny pracy, za które mógłby on zostać ukarany karą porządkową. Wskazana regulacja ma charakter wyjątkowy, bowiem obejmuje ona ochroną pracowników niewywiązujących się z podstawowych obowiązków wykonywania pracy sumiennie i starannie $\mathrm{w}$ czasie pracy ustalonym $\mathrm{w}$ danym zakładzie pracy oraz stosowania się do poleceń przełożonego (art. 100 §1 i 2 k.p.). Należy jednak mieć na uwadze, że poprzez nieuwzględnienie pracowniczego prawa do przerwy pracodawca również narusza swoje podstawowe obowiązki w zakresie organizacji pracy. Przy planowaniu zajęć oraz ustalaniu grafiku dyżurów, dyrek-

\footnotetext{
${ }^{44}$ A.M. Świątkowski, Kodeks pracy. Komentarz, Warszawa 2018, s. 690-691.

45 Por. wyrok Sądu Najwyższego z 09.05.2000 r., I PKN 619/99, Legalis.
} 
tor szkoły związany jest więc nie tylko zapisami art. 42 ust. 1-3 KartaNauczU oraz Rozporządzenia Ministra Edukacji Narodowej z 31.12.2002 r. w sprawie bezpieczeństwa i higieny w publicznych i niepublicznych szkołach i placów$\mathrm{kach}^{46}$, ale również przepisami ogólnego prawa pracy, które dla higieny pracy nauczyciela, ale przede wszystkim dla stwarzania warunków bezpiecznego pobytu na terenie placówki i uczestnictwa w organizowanych przez nią zajęciach uczniów, mają kluczowe znaczenie. Trudno bowiem oczekiwać, aby pedagog w sposób równie sumienny i staranny sprawował ustawiczny nadzór nad dziećmi i młodzieżą. Nieuwzględnienie zmęczenia pracującego dydaktycznie i wychowawczo na lekcji oraz dyżurującego na przerwach międzylekcyjnych nauczyciela jako czynnika ryzyka powinno stanowić okoliczność obciążającą dyrektora w sytuacji gdy dochodzi do wypadku z udziałem ucznia.

Odpowiedzialność porządkowa nie może być stosowana wobec osób, którym dyrektor zarzuca wyłącznie brak sumienności czy staranności, nieprzejawianie inicjatywy, czy brak wysiłków w kierunku podwyższania jakości swojej pracy ${ }^{47}$. Z uwagi jednak na wyartykułowane w KartaNauczU (art. 6) obowiązki nauczyciela w postaci dążenia do pełni własnego rozwoju osobowego i zgodnego z potrzebami szkoły doskonalenia zawodowego, dyrektor może go ukarać nieprzyznaniem nagrody, ewentualnie dodatku motywacyjnego, bądź pozbawieniem uprawnień uzależnionych od nienagannego wykonywania obowiązków. Ponadto, objawy nienagannego stosunku do pracy, niekwalifikujące się jako nienależyte świadczenie pracy, stanowią przedmiot oceny pracownika dokonywanej przez dyrektora $\mathrm{w}$ ramach wewnętrznego nadzoru pedagogicznego ${ }^{48}$.

\section{Odpowiedzialność dyscyplinarna nauczycieli}

Reżim odpowiedzialności dyscyplinarnej jest szczególnym - w stosunku do odpowiedzialności pracowniczej, cywilnej, czy karnej - rodzajem odpowiedzialności, właściwym dla danej pragmatyki zawodowej. Wynika to z jej ścisłego związania $\mathrm{z}$ faktem wykonywania określonej profesji ${ }^{49}$. W przypadku nauczycieli problematyka ta dotyczy wszystkich przedstawicieli zawodu, niezależnie od podstawy zatrudnienia oraz posiadanego stopnia awansu za-

${ }^{46}$ DzU z 2003 r., nr 6, poz. 69. Zgodnie z $\$ 4$ tego rozporządzenia, plan zajęć dydaktyczno-wychowawczych uwzględnia: 1) równomierne obciążenie uczniów zajęciami w poszczególnych dniach tygodnia; 2) zróżnicowanie zajęć w każdym dniu; 3) możliwości psychofizyczne uczniów podejmowania intensywnego wysiłku umysłowego w ciągu dnia.

47 T. Konarska, Szkolne prawo pracy, s. 369.

${ }^{48}$ Zgodnie $\mathrm{z}$ art. 6a ust. 1e KartaNauczU, dyrektor dokonujący oceny pracy konkretnego nauczyciela uwzględnia stopień wywiązywania się przez niego z zadań wymienionych $\mathrm{w}$ art. 6 KartaNauczU, w art. 42 ust. 2 oraz w art. 5 PrOświat w zakresie wszystkich obszarów działalności szkoły.

49 A. Piszko, Karta Nauczyciela. Komentarz, Warszawa 2017, s. 308. 
wodowego, i stanowi przedmiot regulacji rozdziału $10 \mathrm{KartaNaucz}^{50}$. Niezależnie od powyższego KartaNauczU w kwestii szczegółowego trybu prowadzenia postępowania wyjaśniającego i dyscyplinarnego odsyła do przepisów wykonawczych $^{51}$ (art. 85v), co sprawia, że zagadnienia proceduralne dotyczące odpowiedzialności dyscyplinarnej nauczycieli stają się materią bardzo szczegółowo unormowaną, zbliżoną $\mathrm{w}$ wielu punktach do procedury karnej (przepisy karne z uwagi na dyspozycję art. 85i KartaNauczU mają niekiedy do postępowań dyscyplinarnych bezpośrednie zastosowanie, co świadczy również o penalnym charakterze tego reżimu odpowiedzialności).

Z punktu widzenia zadań dyrektora zatrudniającego nauczyciela, w stosunku do którego mają zastosowanie wskazane wyżej przepisy, podstawowe znaczenie przypisać należy regulacjom dotyczącym: podstaw wszczęcia postępowania dyscyplinarnego; zawieszenia w pełnieniu obowiązków nauczyciela; stwierdzenia wygaśnięcia stosunku pracy.

Zgodnie z treścią art. 75 ust. 1 KartaNauczU nauczyciel pociągnięty zostaje do odpowiedzialności dyscyplinarnej w sytuacji uchybienia obowiązkom $\mathrm{z}$ art. 6 lub uchybienia godności zawodu, przy czym w orzecznictwie podkreśla się, że podstawy te stanowią przesłanki, których wystąpienie w konkretnym przypadku należy rozpatrywać odrębnie. Zdarzyć się bowiem może sytuacja, kiedy nauczyciel swoim zachowaniem nie narusza wiążących go standardów wykonywania zawodu, jednak dokonuje naruszeń w zakresie nauczycielskich obowiązków ${ }^{52}$. Dyrektor po dokonaniu ustaleń, z których wynika, iż jego pracownik uchyla się od sumiennego i starannego realizowania spoczywających nań zadań, ma obowiązek poinformować o tej okoliczności rzecznika dyscyplinarnego, chyba że podejmie decyzję o ukaraniu podwładnego karą porządkową z uwagi na charakter naruszeń związanych z porządkiem na terenie zakładu pracy. Obowiązek informowania dotyczy

${ }^{50}$ Zawarte w przywołanym rozdziale przepisy odnoszą się przede wszystkim do zagadnień proceduralnych, związanych z: właściwością dwuinstancyjnych komisji dyscyplinarnych; powoływaniem i odwoływaniem członków komisji oraz jej przewodniczącego; składem orzekającym w danej sprawie; powołaniem rzecznika dyscyplinarnego i jego wyłączeniem w konkretnej sprawie; wszczęciem postępowania wyjaśniającego; wszczęciem i odmową wszczęcia postępowania dyscyplinarnego; prawem do korzystania z obrońcy; zawieszeniem i odroczeniem postępowania; rodzajem środków dowodowych i ich przeprowadzaniem; dyrektywami wymiaru kar dyscyplinarnych; procedurą odwoławczą; przedawnieniem postępowania oraz zatarciem skazania; funkcjonowaniem centralnego rejestru orzeczeń dyscyplinarnych.

${ }^{51}$ Chodzi o Rozporządzenie Ministra Edukacji Narodowej z 25.05.2016 r. w sprawie szczegółowego trybu prowadzenia postępowania wyjaśniającego i dyscyplinarnego wobec nauczycieli oraz wznawiania postępowania dyscyplinarnego, DzU z 2016 r. poz. 741.

52 Por. wyrok Sądu Apelacyjnego w Białymstoku z 11.09.2013 r., III APo 3/13. W uzasadnieniu do wyroku Sąd podkreślił, iż „,odpowiedzialność dyscyplinarną za naruszenie obowiązków, o których mowa w art. 6 ustawy nauczyciel ponosi nawet wówczas, gdy naruszenie tych obowiązków nie ma cech uchybienia godności zawodu nauczyciela"; http://orzeczenia.bialystok.sa.gov.pl [dostęp: 27.01.2020]. 
również zachowań uchybiających godności zawodu, przy czym warto podkreślić, iż KartaNauczU nie zawiera legalnej definicji tego pojęcia, co sprawia, iż pod tym ogólnym sformułowaniem kryć się może szeroki zakres stanów faktycznych. Z pewnością uchybienie godności zawodu nauczyciela jest zachowaniem przynoszącym ujmę randze tego zawodu i funkcji pełnionej w społeczeństwie. Można je w zasadzie utożsamiać z naruszeniem obowiązku godnego zachowania, którego wzorzec konstruowany jest na podstawie przepisów prawa, norm etyki zawodowej i innych norm moralnych ${ }^{53}$.

Zbyt małe sprecyzowanie podstawy odpowiedzialności związanej z przesłanką uchybienia godności zawodu oraz brak kodyfikacji zasad etyki nauczyciela sprawiają, że dyrektorzy w konkretnych przypadkach, podobnie jak organy decydujące o wszczynaniu postępowania wyjaśniającego i dyscyplinarnego, mogą borykać się z wątpliwościami interpretacyjnymi. Z drugiej strony, analiza przepisów KartaNauczU w części poświęconej zagadnieniu odpowiedzialności dyscyplinarnej daje podstawy do przypisania dyrektorowi ograniczonej roli $\mathrm{w}$ tej procedurze. Jest on bowiem przede wszystkim podmiotem informującym o okolicznościach stanowiących podstawę inicjowania działań organów dyscyplinarnych, którego autonomia gwarantowana $\mathrm{w}$ porządku wyznaczonym przez prawo pracy ulega ograniczeniu w sytuacji naruszenia praw i dobra dziecka ${ }^{54}$. Dyrektor nie rozstrzyga o zaistnieniu przesłanek pociągnięcia obwinionego nauczyciela do odpowiedzialności, o zasadności jego ukarania, czy rodzaju kary; gwarancja niezawisłości orzeczniczej komisji dyscyplinarnej (art. 85a KartaNauczU) sprawia, że jego stanowisko $\mathrm{w}$ sprawie nauczyciela, prezentowane $\mathrm{w}$ drodze składania zeznań jako świadek, jest co najwyżej traktowane jako jeden z licznych środków dowodowych (art. 85g KartaNauczU).

Należy równocześnie podkreślić, że przepisy dyscyplinarne nakładają na dyrektora konkretne zadania o charakterze zabezpieczającym. Może on bowiem zawiesić w pełnieniu obowiązków nauczyciela, przeciwko któremu złożono wniosek o wszczęcie postępowania dyscyplinarnego (a w przypadkach niecierpiących zwłoki nawet przed złożeniem takiego wniosku), jeżeli uzna, iż ze względu na powagę i wiarygodność wysuniętych zarzutów celowe jest odsunięcie nauczyciela od wykonywania obowiązków w szkole (art. 85t ust. 2 KartaNauczU). Oceny zasadności zawieszenia dokonuje dyrektor, co oznacza, że nawet jeśli oceni, że zarzuty spełniają kryteria wagi i wiarygodno-

${ }^{53}$ A. Kamińska, Odpowiedzialność dyscyplinarna nauczycieli w świetle regulacji zawartych w Karcie Nauczyciela i innych przepisach, Studia Prawnicze i Administracyjne, 2019, 29, s. 21.

${ }^{54}$ Zgodnie bowiem z brzmieniem dodanego do KartaNauczU ustawą nowelizacyjną z 13.06.2019 r. (DzU z 2019 r. poz. 1287) art. 75 ust. 2a, kar porządkowych nie wymierza się za popełnienie czynu naruszającego prawa i dobro dziecka. O popełnieniu przez nauczyciela czynu naruszającego prawa i dobro dziecka dyrektor szkoły zawiadamia rzecznika dyscyplinarnego nie później niż w ciągu 3 dni roboczych od dnia powzięcia wiadomości o popełnieniu czynu. 
ści, jego decyzja jest niezależna ${ }^{55}$. Jeśli jednak zostanie wszczęte postępowanie karne lub złożono wniosek o wszczęcie postępowania dyscyplinarnego dotyczącego czynu naruszającego prawa i dobro dziecka, zawieszenie nauczyciela jest obowiązkiem dyrektora (art. 85t ust. 2 KartaNauczU), co sprawia, że staje się on gwarantem ochrony interesów uczniów, uruchamiającym swoje pracownicze prerogatywy w sytuacji zaistnienia podejrzeń, weryfikowanych na późniejszych etapach przez organy karne i dyscyplinarne. Decyzja dyrektora o zawieszeniu w pełnieniu obowiązków może zostać uchylona jedynie przez komisję dyscyplinarną pierwszej instancji, do której przysługuje odwołanie, co wyłącza kognicję sądów administracyjnych oraz sądów pracy, dodatkowo wskazując na specyficzną rolę, w jakiej w tego typu sprawach występuje przełożony obwinionego nauczyciela ${ }^{56}$.

\section{Zakończenie}

Szkoła dla osób zatrudnionych na stanowiskach pedagogicznych stanowi przede wszystkim ich miejsce pracy. Łączący ich z dyrektorem stosunek pracowniczy narzuca podległość służbową, w tym obowiązek realizowania poleceń przełożonego. $Z$ przepisów prawa pracy wynika szeroki zakres dyrektorskiej autonomii, wyrażający się w samodzielnym prowadzeniu polityki kadrowej. Dyrektor podejmuje więc decyzje dotyczące doboru wykwalifikowanej pod względem merytorycznym i wyposażonej w kompetencje pedagogiczne kadry nauczycielskiej, przydziału obowiązków pracowniczych, czy pociągania nauczycieli do odpowiedzialności porządkowej. Z uwagi jednak na dyspozycję art. 5 k.p. do nauczycielskich stosunków pracy mają zastosowanie przepisy szczególne, zwłaszcza KartaNauczU. Z brzmienia jej przepisów, jak również innych regulacji prawa oświatowego wynika szczególny charakter stanowiska osoby zarządzającej placówką oświatową. Od tego, jak dyrektor realizuje spoczywające na nim jako pracodawcy obowiązki w znacznym stopniu zależy jakość realizowanych przez szkołę procesów dydaktyczno-wychowawczych oraz opiekuńczych. W tym kontekście założenie posiadania przez niego osobowościowego przymiotu w postaci nieskazitelnego charakteru nabiera realnego znaczenia wypełnianego treścią szeregu decyzji podejmowanych w ramach stosunków pracowniczych ${ }^{57}$.

\footnotetext{
55 T. Konarska, Szkolne prawo pracy, s. 361.

56 Por. postanowienie Naczelnego Sądu Administracyjnego z 06.09.2012 r., I OSK 1831/12, Legalis.

${ }^{57}$ Por. wyrok Sądu Apelacyjnego we Wrocławiu z 03.04.2012 r., APo 5/11, http:/ / orzeczenia.wroclaw.sa.gov.pl [dostęp: 27.01.2020].
} 


\section{BIBLIOGRAFIA}

Barański A., Szymańska M., Rozwadowska-Skrzeczyńska J., Karta Nauczyciela. Komentarz, Wydawnictwo Wolters Kluwer, Warszawa 2018.

Homplewicz J., Kierunki rozwoju prawa szkolnego w Polsce, [w:] Prawo. Administracja. Gospodarka. Księga ku czci Profesora Ludwika Bara, red. J. Łętowski, J.P. Pruszyński, Ossolineum, Wrocław 1983.

Kamińska A., Odpowiedzialność dyscyplinarna nauczycieli w świetle regulacji zawartych w Karcie Nauczyciela i innych przepisach, Studia Prawnicze i Administracyjne, 2019, 29.

Komorowski T., Pielachowski J., Dyrektor szkoły w roli pracodawcy, Wydawnictwo eMPi2, Poznań 2004.

Konarska T., Szkolne prawo pracy. Poradnik dyrektora szkoty, Wydawnictwo Wolters Kluwer, Warszawa 2019.

Pilich M., Ustawa o systemie oświaty, Wydawnictwo Wolters Kluwer, Warszawa 2015.

Pyter M., Balicki A., Prawo oświatowe. Komentarz, Wydawnictwo C.H.Beck, Warszawa 2017. Roszewska K., Tajemnica zawodowa nauczyciela, MoP, 2014, 24.

Rudzińska Z., Nadzór pedagogiczny w przedszkolu i szkole - praktyczne zastosowanie nowych przepisów, Wiedza i Praktyka, Warszawa 2019.

Skoczyński J., Dzienisiuk D., Rozdział I. Obowiazki pracodawcy, [w:] Kodeks pracy. Komentarz, red. L. Florek, Wydawnictwo Wolters Kluwer, Warszawa 2017.

Świątkowski A.M., Kodeks pracy. Komentarz, Wydawnictwo C.H.Beck, Warszawa 2018.

Zieliński T., Goździewicz G., Rozdziat I. Przepisy wstępne, [w:] Kodeks pracy. Komentarz, red. L. Florek, Wydawnictwo Wolters Kluwer, Warszawa 2017.

Zieliński T., Pisarczyk Ł., Rozdział III. Stosunek pracy na podstawie powołania, wyboru, mianowania oraz spótdzielczej umowy o prace, [w:] Kodeks pracy. Komentarz, red. L. Florek, Wydawnictwo Wolters Kluwer, Warszawa 2017.

\section{Akty prawne}

Ustawa z 23.04.1964 r. Kodeks cywilny, t.j. DzU z 2019 r. poz. 1145 ze zm.

Ustawa z 26.06.1974 r. Kodeks pracy, t.j. DzU z 2019 r. poz. 1495 ze zm.

Ustawa z 26.01.1982 r. Karta Nauczyciela, t.j. DzU z 2019 r. poz. 2215.

Ustawa z 13.05.2016 r. o przeciwdziałaniu zagrożeniom przestępstwami na tle seksualnym, t.j. DzU z 2018 r. poz. 405 ze zm.

Ustawa z 14.12.2016 r. Prawo oświatowe, t.j. DzU z 2019 r. poz. 1148 ze zm.

Rozporządzenie Ministra Zdrowia i Opieki Społecznej z 30.05.1996 r. w sprawie przeprowadzania badań lekarskich pracowników, zakresu profilaktycznej opieki zdrowotnej nad pracownikami oraz orzeczeń lekarskich wydawanych do celów przewidzianych w Kodeksie pracy, DzU z 2016 r. poz. 2067.

Rozporządzenie Ministra Edukacji Narodowej z 31.12.2002 r. w sprawie bezpieczeństwa i higieny w publicznych i niepublicznych szkołach i placówkach, DzU z 2003 r., nr 6, poz. 69.

Rozporządzenie Ministra Edukacji Narodowej z 01.08.2017 r. w sprawie szczegółowych kwalifikacji wymaganych od nauczycieli, DzU z 2017 r. poz. 1575.

\section{Orzecznictwo Sądu Najwyższego i sądów powszechnych}

Wyrok Sądu Najwyższego z 05.05.1975 r., II CR 153/75, Legalis.

Uchwała Sądu Najwyższego z 16.11.1977 r., I PZP 47/77, Legalis.

Wyrok Sądu Najwyższego z 05.11.1998 r., I PKN 420/98, Legalis.

Wyrok Sądu Najwyższego z 19.02.2000 r., II PKN 156/08, Legalis. 
Wyrok Sądu Najwyższego z 09.05.2000 r., IPKN 619/99, Legalis.

Wyrok Sądu Najwyższego z 22.09.2000 r., I PKN 29/00, Legalis.

Wyrok Sądu Najwyższego z 11.09.2001 r., I PKN 610/00, Legalis.

Wyrok Sądu Apelacyjnego we Wrocławiu z 03.04.2012 r., APo 5/11, http://orzeczenia. wroclaw.sa.gov.pl.

Wyrok Sądu Apelacyjnego w Białymstoku z 11.09.2013 r., III APo 3/13, http:/ / orzeczenia. bialystok.sa.gov.pl.

Wyrok Sądu Najwyższego z 20.02.2014 r., III PK 71/13, Legalis.

Wyrok Sądu Najwyższego z 22.01.2015 r., III PK 56/14, Legalis.

Wyrok Sądu Najwyższego z 26.05.2017 r., I CSK 557/16, Legalis.

\section{Orzecznictwo NSA i wojewódzkich sądów administracyjnych}

Wyrok Naczelnego Sądu Administracyjnego z 27.11.2001 r., II SA 2133/01, Legalis.

Postanowienie Naczelnego Sądu Administracyjnego z 06.09.2012 r., I OSK 1831/12, Legalis.

Wyrok Wojewódzkiego Sądu Administracyjnego w Warszawie z 30.12.2014 r., II SA/Wa 929/14, http:/ / orzeczenia.nsa.gov.pl.

Wyrok Naczelnego Sądu Administracyjnego z 06.08.2015 r., I OSK 901/15, http:/ /orzeczenia.nsa.gov.pl. 